\title{
Frequency of Paroxysmal Nocturnal Hemoglobinuria Clone in Turkish Myelodysplastic Syndrome Group
}

\author{
Türk Myelodisplastik Sendrom Hasta Grubunda Paroksismal Noktürnal \\ Hemoglobinüri Klonu Sıklığı
}

\author{
(1) Mesut Ayer, (1) Merve Öztürk Çiloğlu*, (1) Fuat Şar* , (D) Esra Hayriye Ataoğlu*, \\ (1) Fatma Aylin Ayer*, (1) Tayfun Elibol** , (1) Onur Hakkı Kırkızlar*** \\ University of Health Sciences, Haseki Training and Research Hospital, Clinic of Hematology, Istanbul, Turkey \\ *University of Health Sciences, Haseki Training and Research Hospital, Clinic of Internal Medicine, Istanbul, Turkey \\ **Marmara University, Pendik Training and Research Hospital, Clinic of Hematology, Istanbul, Turkey \\ ${ }^{* * * M e d e n i y e t ~ U n i v e r s i t y, ~ G o ̈ z t e p e ~ T r a i n i n g ~ a n d ~ R e s e a r c h ~ H o s p i t a l, ~ C l i n i c ~ o f ~ H e m a t o l o g y, ~ I s t a n b u l, ~ T u r k e y ~}$
}

Abstract

Aim: Retrospective, cross-sectional, observational study to examine the frequency and features of paroxysmal nocturnal hemoglobinuria (PNH) clones in patients with myelodysplastic syndrome (MDS).

Methods: Data were analyzed from the medical files of 41 MDS patients diagnosed and followed up in the hematology department at a referral center between 2006 and 2017. Descriptive data, cytogenetic and hematologic characteristics, prognostic features and PNH clone sizes were assessed. PNH clone sizes were evaluated using the fluorescently labeled inactive toxin aerolysin method.

Results: The study population comprised 22 (53.7\%) female and $19(46.3 \%)$ male patients with confirmed MDS; the mean age of the patients was 68.20 \pm 9.84 years (range, 45-85). PNH clones were detected in eight (19.5\%) patients. The number of patients with a PNH clone size of $>10 \%,>1 \%,>0.1 \%$ and $>0.01 \%$ was one, one, one and eigth, respectively ( $p<0.001$ for all subgroups).

Conclusion: These data indicate that PNH clones exist in approximately one-fifth of MDS patients. Further studies on a more extensive cohort are required to better understand the pathophysiological and clinical relationships between MDS and $\mathrm{PNH}$.

Keywords: Paroxysmal nocturnal hemoglobinuria, myelodysplastic syndrome, FLAER
Öz

Amaç: Türk miyelodisplastik sendrom (MDS) hasta grubunda retrospektif, kesitsel, gözlemsel çalışma ile paroksismal noktürnal hemoglobinüri (PNH) klon sıklığı ve özellikleri araştııımıştır.

Yöntemler: Hematoloji bölümümüzde 2006-2017 yılları arasında takip edilen 41 MDS hastasının verileri analiz edildi. Sitogenetik, hematolojik ve prognostik ve karakteristik özellikler, PNH klon varlığı değerlendirildi. PNH klonu taraması için floresan ile işaretlenmiş inaktif toksin aerolizin metodu kullanıldı.

Bulgular: Çalışma grubu teyit edilmiş MDS tanılı $22(\% 53,7)$ kadın ve

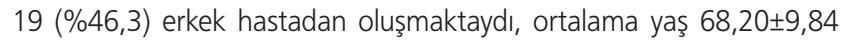
(aralık, 45-85) idi. Sekiz hastada (\%19,5) PNH klonu saptandı. PNH klon genişliği >\%10, >\%1, >\%0,1, >\%0,01 olarak sırasıyla; bir, bir, bir ve sekiz hastada ( $p<0,001$ tüm alt gruplarda) saptandı.

Sonuç: MDS hasta grubumuzun yaklaşık $1 / 5^{\prime}$ inde PNH klonu saptanmıştır. MDS ve PNH arasındaki klinik ve patofizyolojik ilişkinin daha iyi anlaşılması için geniş olgu serilerinde yapılacak çalışmalara ihtiyaç vardır.

Anahtar Sözcükler: Paroksismal noktürnal hemoglobinüri, miyelodisplastik sendrom, FLAER

\section{Introduction}

Myelodysplastic syndrome (MDS) is a clonal disease of hematopoietic stem cells characterized by cytopenias due to ineffective hematopoiesis. It occurs more commonly in advanced age and can transform into acute myeloid leukemia. Even though an etiologic factor cannot be identified in the vast majority of patients, exposure to benzene, chemotherapeutics, topoisomerase inhibitors 
and radiation are among predisposing factors for MDS (1). Refractory anemia (RA) with erythroid dysplasia, ring sideroblasts or cytopenias with multiple dysplasia as well as blastic changes in bone marrow can be observed in MDS, and common clinical symptoms include increased bleeding, frequency of infections, fatigue and weakness. However, some cases can stay dormant without any symptoms. A diagnosis of MDS is confirmed by peripheral smear, bone marrow aspiration and biopsy. Cytogenetic analysis and fluorescence in situ hybridization can also assist in estimating prognosis and determining disease subgroups.

Paroxysmal nocturnal hemoglobinuria (PNH) is a chronic, progressive, life-threatening, rare, and multisystemic disease, developing as a result of somatic mutation of hematopoietic stem cell, and characterized by clonal, complement-mediated intravascular hemolysis (2).

$\mathrm{PNH}$ is caused by a somatic mutation of the phosphatidylinositol glycan A gene, which results in a partial or complete absence of synthesis of glucosylphosphatidylinositol cell membrane anchors and a subsequent deficiency (or total lack) of CD55 and CD59 cell-surface proteins of progeny cell populations (3). Clinically, PNH manifests with chronic intravascular hemolysis, bone marrow insufficiency and thrombosis, with patients generally grouped according to hemolytic or hypoplastic subtypes. The hemolytic type presents with chronic intravascular hemolysis, while pancytopenia is the most common symptom in the hypoplastic type.

Classical PNH may exist individually or may be accompanied by aplastic anemia (AA) or MDS. The gold standard technique for the diagnosis of $\mathrm{PNH}$ is based on the determination of proteins, such as CD55 and CD59 by flow cytometry, using two surface antibodies in at least two cell groups, including granulocytes.

There are no widely accepted evidence-based indications for the treatment of $\mathrm{PNH}$. In classic $\mathrm{PNH}$, eculizumab is recommended for patients with disabling fatigue, thromboses, transfusion dependence, frequent pain paroxysms, renal insufficiency, or other endorgan complications of the disease. Watchful waiting is appropriate for asymptomatic patients or those with mild symptoms. In patients with AA/PNH, therapy should be directed toward the underlying bone marrow failure with careful monitoring of the PNH clone using flow cytometry. Patients who meet criteria for severe AA should be managed with either allogeneic bone marrow transplantation or immunosuppressive therapy depending on the age of the patient and the availability of a suitable human leukocyte antigen-matched sibling donor (4).

Investigations for $\mathrm{PNH}$ are recommended in MDS patients with RA, and an increased incidence of PNH (10-
$17 \%)$ has been reported among patients with MDS (5-12). We report data from a study that evaluated the frequency of $\mathrm{PNH}$ in our MDS patients with RA.

\section{Methods}

\section{Study Design}

This retrospective, cross-sectional, observational study was based on clinical chart data from patients treated in the hematology department at a tertiary care center in Istanbul, Turkey between 2006 and 2017. All patients with a confirmed diagnosis of MDS based on relevant diagnostic tests and classified according to the World Health Organization (WHO) and French-American-British (FAB) criteria were included.

Study assessments and methods were approved by the local institutional review board (Haseki Training and Research Hospital Ethic Committee, no: 75/date: 03.01.2014) and were conducted in accordance with the current version of the Helsinki Declaration. Written informed consent was obtained from all patients for inclusion and publication of anonymized data.

\section{Sampling and Paroxysmal Nocturnal Hemoglobinuria Clone Analysis}

Blood samples were collected in ethylenediaminetetraacetic acid tubes by peripheral venipuncture and were kept at room temperature. $\mathrm{PNH}$ clone analyses were conducted within 24 hours of sampling. Clones were analyzed in granulocytes according to the fluorescently labeled inactive toxin aerolysin (FLAER) method using commercially available kits (Becton Dickinson, New Jersey, USA, Cedarlane Labs, Burlington/ Ontario, Canada).

\section{Outcome Measures}

Demographic data, including age, gender, and coexisting systemic diseases were collated to characterize the patient cohort. Flow-cytometry-derived PNH clone sizes were evaluated to assess the extent of $\mathrm{PNH}$. Other outcomes measures included the Eastern Cooperative Oncology Group (ECOG) performance status scale (13), the International Prognostic Scoring System (IPSS) score, patient survival periods, and the magnitude of cytopenia (12).

\section{Statistical Analysis}

Statistical analysis was performed using the Statistical Package for Social Sciences Program version 16.0 (SPSS Inc., Chicago, IL, USA). Descriptive data were expressed in terms of frequency and percentages, mean \pm standard deviation and/or median \pm interquartile range. 


\section{Results}

\section{Patients and Disease Characteristics}

The study population comprised 22 (54\%) female and $19(46 \%)$ male patients with a confirmed diagnosis of MDS. The mean age of the subjects was 68.2 \pm 9.8 (range, 45-85) years. The most frequent concurrent systemic diseases accompanying MDS were hypertension, diabetes mellitus and ischemic heart disease, observed in $22 \%$ of patients each.

The distributions of MDS patients categorised with respect to the FAB and WHO classifications, and the presence of PNH clones, are shown in Tables 1, 2, Figures 1,2 respectively. Based on the FAB system, MDS was recorded as most frequently classified as RA, with five

\begin{tabular}{|c|c|c|c|}
\hline \multirow[t]{2}{*}{ FAB MDS type } & \multicolumn{2}{|c|}{ PNH clone } & \multirow[t]{2}{*}{ Total } \\
\hline & No & Yes & \\
\hline MDS-U & 1 & 0 & 1 \\
\hline RA & 19 & 5 & 24 \\
\hline RAEB & 4 & 1 & 5 \\
\hline RAEB-2 & 1 & 0 & 1 \\
\hline RAEB-t & 1 & 0 & 1 \\
\hline RARS & 7 & 2 & 9 \\
\hline Total & 33 & 8 & 41 \\
\hline \multicolumn{4}{|c|}{$\begin{array}{l}\text { MDS-U: Myelodisplastic syndrome unclassified, PNH: Paroxysmal nocturnal } \\
\text { hemoglobinuria, RA: Recractory anemia, RAEB: Recractory anemia excess } \\
\text { blast, RAEB-t: Refractory anemia with excess blasts in transformation, RARS: } \\
\text { Recractory anemia with ring sideroblasts, FAB: French-American-British }\end{array}$} \\
\hline
\end{tabular}

\begin{tabular}{|c|c|c|c|}
\hline \multirow[t]{2}{*}{ WHO MDS type } & \multicolumn{2}{|c|}{ PNH clone } & \multirow[t]{2}{*}{ Total } \\
\hline & No & Yes & \\
\hline MDS-U & 1 & 0 & 1 \\
\hline RA & 12 & 1 & 13 \\
\hline RAEB-1 & 5 & 0 & 5 \\
\hline RAEB-2 & 1 & 1 & 2 \\
\hline RA-isolated del5q & 0 & 2 & 2 \\
\hline RARS & 3 & 1 & 4 \\
\hline RCMD & 11 & 2 & 13 \\
\hline RCUD & 0 & 1 & 1 \\
\hline Total & 33 & 8 & 41 \\
\hline \multicolumn{4}{|c|}{$\begin{array}{l}\text { MDS-U: Myelodisplastic syndrome unclassified, PNH: Paroxysmal nocturnal } \\
\text { hemoglobinuria, RA: Recractory anemia, RAEB: Recractory anemia excess blast, } \\
\text { RARS: Recractory anemia with ring sideroblasts, RCMD: Refractory cytopenia } \\
\text { with multilineage dysplasia, RCUD: Refractory cytopenia with unilineage } \\
\text { dysplasia, WHO: World Health Organization }\end{array}$} \\
\hline
\end{tabular}

patients confirmed as having PNH clones. Using the WHO system, equal numbers of patients overall were classified with RA or refractory cytopenia with multilineage dysplasia; but together these classifications contributed only three patients to the overall total; PNH-positive patients were therefore spread over a wider range of categories under the WHO system.

\section{Cytogenic Characteristics}

Cytogenetic findings in this cohort are summarized in Table 3. The percentage of myeloblasts in bone marrow biopsy were $<5 \%$ in 36 patients (88\%), $5-10 \%$ in three $(7 \%)$, and $10-20 \%$ in three patients $(5 \%)$. PNH clones were detected in eight (20\%) patients overall.

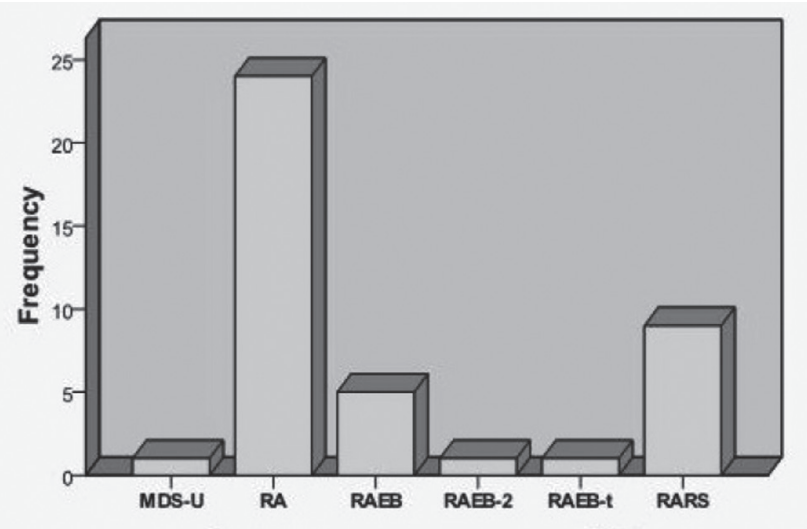

Figure 1. French-American-British classification of patients MDS-U: Myelodisplastic syndrome unclassified, RA: Recractory anemia, RAEB: Recractory anemia excess blast, RAEB-t: Refractory anemia with excess blasts in transformation, RARS: Recractory anemia with ring sideroblasts

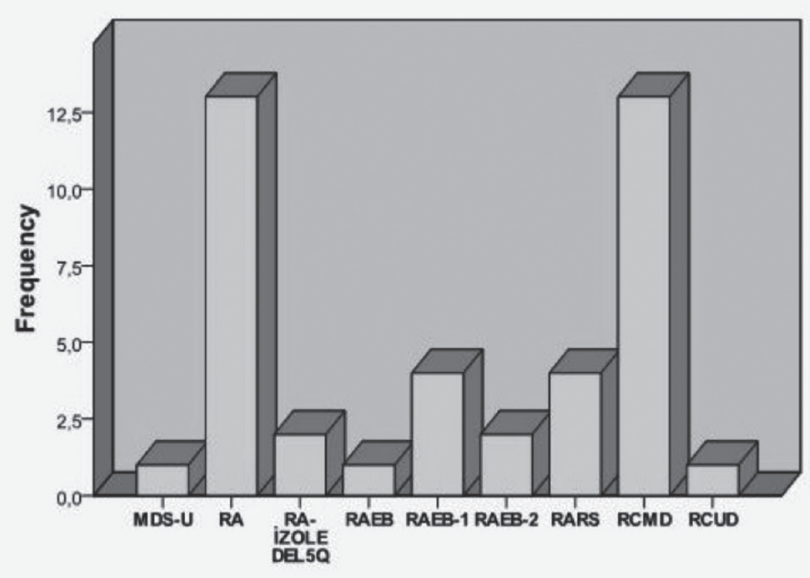

Figure 2. World Health Organization classification of patients MDS-U: Myelodisplastic syndrome unclassified, RA: Recractory anemia, RAEB: Recractory anemia excess blast, RARS: Recractory anemia with ring sideroblasts, RCMD: Refractory cytopenia with multilineage dysplasia, RCUD: Refractory cytopenia with unilineage dysplasia 


\section{Outcome Measures}

Results from evaluations of all patients according to the IPSS are summarized in Figure 3. Twenty-four cases were identified in the Int-1 risk group (59\%), three patients

\begin{tabular}{|c|c|}
\hline & $\begin{array}{l}\text { Frequency and } \\
\text { percent }(\%)\end{array}$ \\
\hline $11 q 23$ (del) & $1(2.4)$ \\
\hline $46 \times X$ & $16(39)$ \\
\hline $46 X Y$ & $16(39)$ \\
\hline $47 X X+8$ & $1(2.4)$ \\
\hline add (1) p32-36 [18] & $1(2.4)$ \\
\hline del (11) (q13q23), der5, der12, der18 & $1(2.4)$ \\
\hline $\operatorname{del}(20)(q 11,2)$ & $1(2.4)$ \\
\hline del (5) (q31q35) +8, -18 & $1(2.4)$ \\
\hline del 5 (q12q33[16] & $1(2.4)$ \\
\hline del5q & $1(2.4)$ \\
\hline Insufficient metaphase & $1(2.4)$ \\
\hline
\end{tabular}

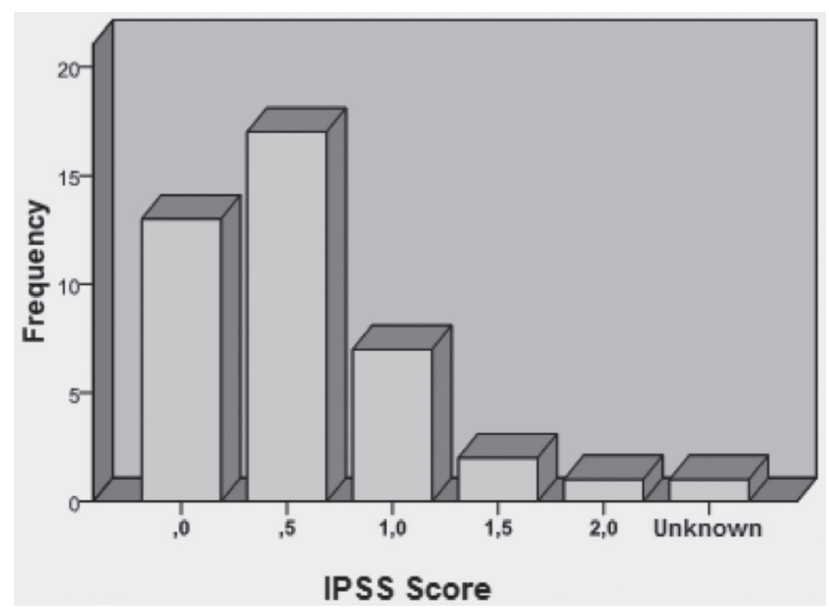

Figure 3. Distribution of International Prognostic Scoring System scores in myelodisplastic syndrome patients

IPSS: International Prognostic Scoring System

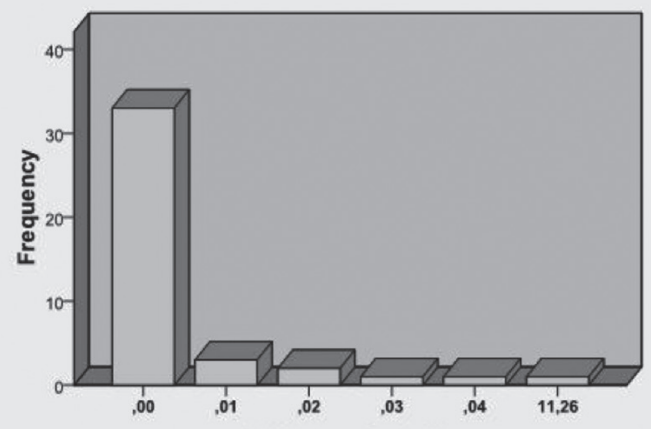

Figure 4. Frequency of paroxysmal nocturnal hemoglobinuria clone size were diagnosed with Int-3 (7\%) and 13 MDS patients were in the low-risk group (32\%). Performance status on the ECOG scale revealed a score of 1 in 30 patients (73\%), 1.5 in one patient (2\%), 2 in six patients (15\%), and 3 in one patient (2\%). Median survival times were 3.5 years in 24 patients (59\%), 5.7 years in $12(29 \%)$ and 1.2 years in three patients (7\%).

As illustrated in Table 4 and Figure 4, it can be postulated that $\mathrm{PNH}$ clone size in MDS patients is most frequently very low $(<1 \%)$.

\section{Discussion}

Based on these data, we estimate that $\mathrm{PNH}$, which has previously been linked with MDS and other bone marrow failure syndromes $(2,5)$, occurs in approximately one-fifth of patients with MDS in Turkey.

Due to small PNH clone sizes, patients with MDS may not display obvious signs of hemolysis. However, PNH clone sizes can now be conveniently and accurately determined using modern flow cytometry methods $(5,8,14)$. The pathogenesis of PNH leaves red cells, platelets and neutrophils vulnerable to attack by the complement system, with subsequent hemolysis and platelet activation resulting in severe end-organ damage and a high risk of thrombosis (15). In particular, thrombosis, a major cause of mortality in $\mathrm{PNH}$, is thought to originate from both activation of the complement system and adenosine diphsophat (16).

The link between the immune system and $\mathrm{PNH}$ has not yet been fully elucidated. In addition to deficiencies of CD55 and CD59, immune selection for PNH stem cell proliferation may play a crucial role in $\mathrm{PNH}$ pathogenesis (14). Interestingly, PNH cells have been found to be equivalent to normal cells in terms of their capability to elicit an immune response in tissue cultures (15).

Despite a general agreement that PNH clonal expansion occurs in some MDS patients, some controversial issues exist, including: 1) the type of MDS associated with $\mathrm{PNH}$; 2) techniques adopted for routine laboratory measurement of PNH clones; and 3) the pathophysiological interpretation of PNH clones in MDS. Previously reported data indicate that $\mathrm{PNH}$, as opposed to leukemia, is more likely to exist in MDS patients presenting with bone marrow failure $(17,18)$. However, the prognostic significance of PNH in MDS

\begin{tabular}{|l|l|l|}
\hline \multicolumn{3}{|c|}{$\begin{array}{l}\text { Table 4. Distribution of paroxysmal nocturnal hemoglobinuria } \\
\text { clone sizes }\end{array}$} \\
\hline Clone size & Number $(\%)$ of patients & p value \\
\hline$>0.1$ & $1(2.4)$ & $<0.001$ \\
\hline$>0.01$ & $1(2.4)$ & $<0.001$ \\
\hline$>0.001$ & $1(2.4)$ & $<0.001$ \\
\hline$>0.0001$ & $8(19.5)$ & $<0.001$ \\
\hline
\end{tabular}


patients requires further investigation (5,6). Dysregulation of apoptosis may be involved in pathogenesis of $\mathrm{PNH}$, and the resistance of leukocytes to apoptosis in bone marrow may contribute to selection of a PNH clone. Expansion of the selected $(\mathrm{PNH})$ clone may subsequently lead to clinical manifestations (14).

In a previous prospective multicenter study of $\mathrm{PNH}$ in patients with bone marrow failure, $\mathrm{PNH}$ clones were detected in $17 \%$ of MDS patients based on findings from high sensitivity flow cytometry (19). The detection of even small clone sizes can now be accomplished using the FLAER method, as adopted in the current study. Patients with MDS categorized to the RA group, according to the FAB classification, have been associated with a higher risk of PNH (20). Even though the number of patients in our cohort was too limited to postulate such a relationship, patients with a clone size $>0.1 \%,>1 \%$ and $>10 \%$ were categorized into the RA subgroup. We therefore suggest that the prognostic significance and correlation of RA associated with $\mathrm{PNH}$ should be investigated in further studies.

According to the National Comprehensive Cancer Network guidelines, the detection of PNH clones $>10 \%$ in size is sufficient for the confirmation of a diagnosis of $\mathrm{PNH}$, and a positive result for PNH clones in an MDS patient constitutes an indication for immunosuppressive treatment (21). While we assume that findings from the current study can be extrapolated to the wider MDS patient population, the interpretation of these data is subject to limitations owing to the cohort size and study methodology. Our observations were based on a relatively small number of patients, irrespective of the rarity of PNH in MDS, which makes it difficult to assess pathophysiological links between these two conditions. Moreover, the influence of ethnic or socio-economic factors on our findings cannot be fully assessed. Despite these restrictions, we believe that these data provide an overview of MDS and PNH in Turkey, and serve as a reminder for increased awareness of the possible occurrence of PNH in patients with MDS.

\section{Conclusion}

This study indicates that PNH clones exist in approximately one-fifth of MDS patients. The pathophysiological association between MDS and $\mathrm{PNH}$ needs to be investigated in further clinical studies based on larger, possibly international patient populations.

\section{Authorship Contributions}

Surgical and Medical Practices: M.A. Concept: M.A. Design: M.A. Data Collection or Processing: M.A., M.Ö.Ç. Analysis or Interpretation: M.A., M.Ö.Ç., E.H.A., F.Ş., F.A.A., T.E., O.H.K. Literature Search: M.Ö.Ç., T.E., O.H.K. Writing: M.A., M.Ö.Ç., O.H.K.
Conflict of Interest: No conflict of interest was declared by the authors.

Financial Disclosure: The authors declared that this study received no financial support.

\section{References}

1. Rollison DE, Howlader N, Smith MT, et al. Epidemiology of myelodysplastic syndromes and chronic myeloproliferative disorders in the United States, 2001-2004, using data from the NAACCR and SEER programs. Blood 2008;112:45-52.

2. Sahin F, Akay OM, Ayer M, et al. Pesg PNH diagnosis, followup and treatment guidelines. Am J Blood Res 2016;6:19-27.

3. Rosse $W F$, Ware RE. The molecular basis of paroxysmal nocturnal hemoglobinuria. Blood 1995;86:3277-86.

4. Brodsky RA. How I treat paroxysmal nocturnal hemoglobinuria. Blood 2009;113:6522-7.

5. Young NS. Paroxysmal nocturnal hemoglobinuria and myelodysplastic syndromes: clonal expansion of PIG-A-mutant hematopoietic cells in bone marrow failure. Haematologica 2009;94:3-7.

6. Young NS, Meyers G, Schrezenmeier H, Hillmen P, Hill A. The management of paroxysmal nocturnal hemoglobinuria: recent advances in diagnosis and treatment and new hope for patients. Semin Hematol 2009;46(Suppl 1):1-16.

7. Hillmen P, Lewis SM, Bessler M, Luzzatto L, Dacie JV. Natural history of paroxysmal nocturnal hemoglobinuria. N Engl J Med 1995;333:1253-8.

8. Nakakuma H, Nagakura S, Iwamoto $N$, et al. Paroxysmal nocturnal hemoglobinuria clone in bone marrow of patients with pancytopenia. Blood 1995;85:1371-6.

9. Parker C, Omine M, Richards S, et al. Diagnosis and management of paroxysmal nocturnal hemoglobinuria. Blood 2005; 106:3699-709.

10. Hillmen $P$, Muus $P$, Dührsen $U$, et al. Effect of the complement inhibitor eculizumab on thromboembolism in patients with paroxysmal nocturnal hemoglobinuria. Blood 2007;110:4123-8.

11. Iwanaga M, Furukawa K, Amenomori T, et al. Paroxysmal nocturnal haemoglobinuria clones in patients with myelodysplastic syndromes. Br J Haematol 1998;102:465-74.

12. Greenberg P, Cox C, LeBeau MM, et al. International scoring system for evaluating prognosis in myelodysplastic syndromes. Blood 1997;89:2079-88.

13. Oken MM, Creech RH, Tormey DC, et al. Toxicity and response criteria of the Eastern Cooperative Oncology Group. Am J Clin Oncol 1982;5:649-55.

14. Horikawa K, Nakakuma H, Kawaguchi T, et al. Apoptosis resistance of blood cells from patients with paroxysmal nocturnal hemoglobinuria, aplastic anemia, and myelodysplastic syndrome. Blood 1997;90:2716-22.

15. Hill A, Richards SJ, Hillmen P. Recent developments in the understanding and management of paroxysmal nocturnal haemoglobinuria. Br J Haematol 2007;137:181-92.

16. Hall C, Richards S, Hillmen P. Primary prophylaxis with warfarin prevents thrombosis in paroxysmal nocturnal hemoglobinuria (PNH). Blood 2003;102:3587-91. 
17. Nyland SB, Krissinger DJ, Clemente MJ, et al. Seroreactivity to LGL leukemia-specific epitopes in aplastic anemia, myelodysplastic syndrome and paroxysmal nocturnal hemoglobinuria: results of a bone marrow failure consortium study. Leuk Res 2012;36:581-7.

18. Wang SA, Pozdnyakova O, Jorgensen JL, et al. Detection of paroxysmal nocturnal hemoglobinuria clones in patients with myelodysplastic syndromes and related bone marrow diseases, with emphasis on diagnostic pitfalls and caveats. Haematologica 2009;94:29-37.

19. Raza A, Ravandi F, Rastogi A, et al. A prospective multicenter study of paroxysmal nocturnal hemoglobinuria cells in patients with bone marrow failure. Cytometry B Clin Cytom 2014;86:175-82.

20. Srivastava S, Naseem S, Gupta R, Kashyap R, Chaudhary R. Paroxysmal nocturnal hemoglobinuria clone in a case of myelodysplastic syndrome rapidly progressing to acute leukemia. Indian J Hematol Blood Transfus 2009;25:33-5.

21. NCCN. National Comprehensive Cancer Network (NCCN) Guidelines (2014). [cited 201412 November]; Available from: http://www.nccn.org/professionals/physician_gls/f_ guidelines.asp\#site 